\title{
Desain Jaringan Komputer Terintegrasi Menggunakan Arsitektur Campus LAN
}

\author{
Jeckson Sidabutar \\ Rekayasa Keamanan Siber, Jurusan Keamanan Siber, Politeknik Siber dan Sandi Negara, \\ Jl. Raya H. Usa Desa Putat Nutug Ciseeng, Bogor, Jawa Barat, Indonesia, 16120 \\ e-mail: jeckson.sidabutar@ poltekssn.ac.id
}

\begin{abstract}
The development of Information and Communication Technology (ICT) to access and provide information quickly and accurately becomes very important for an organization (commercial, tertiary, government, or individual). With the rapid development of ICT, it is necessary to consider the dangers and disadvantages of misuse in local network services or in internet-based applications. Campus LAN (Local Area Network) architecture was chosen as the standard used in computer network design. The network architecture approach in this study is a enterprise architecture approach that is used for organizational logic and planning throughout the organization and aims to determine how information technology will support business processes. This method begins by identifying the infrastructure and network security needs, as well as how the information technology system supports the process of activities for all parts of education, administration and other services.
\end{abstract}

Keywords: Campus LAN; Enterprise Architecture; Infrastructure \& Security Network.

\section{PENDAHULUAN}

Pelayanan dan Pengajaran dengan sistem teknologi informasi dan komunikasi (TIK) dapat memperkuat peningkatan mutu pendidikan di Universitas XYZ [1]. Hal ini menunjukan perkembangan TIK menjadi komoditas yang sangat penting dalam menghadapi era revolusi industri 4.0. Kemampuan untuk mengakses informasi dan menyediakannya secara cepat dan akurat menjadi hal yang esensial bagi sebuah organisasi (komersial, perguruan tinggi, pemerintahan, maupun individual) $[1,2,3]$.
Isu kontemporer tentang lambatnya layanan internet di Universitas XYZ bukan hanya disebabkan oleh kecilnya bandwith internet, tetapi faktor desain jaringan area lokal (LAN) yang belum optimal. Banyak orang mendeskripsikan jaringan sebagai media sederhana yang hanya menghubungkan pengguna (user) dengan layanan (service). Sehingga kita tidak perlu mengetahui jumlah paket data yang dikirim dan rute-rute mana saja yang harus dilewatin untuk mengirim paket tersebut. Pengguna hanya peduli pada data yang dikirimkan sampai ketujuan dengan cepat dan tepat. Oleh karena itu desain jaringan yang baik dan terintegrasi membuat paket data berjalan melewati rute-rute yang cepat dan tepat $[1,3]$.

Terdapat beberapa faktor jaringan area lokal di Universitas XYZ yang menyebabkan layanan internet lambat, seperti pada Tabel 1.

Tabel 1 Faktor Penyebab Internet Lambat

\begin{tabular}{|c|c|c|}
\hline No & Faktor & Keterangan \\
\hline 1 & $\begin{array}{l}\text { Perangkat layanan } \\
\text { IT tidak reliability } \\
\text { dan manageability. }\end{array}$ & $\begin{array}{l}\text { Kemampuan perangkat } \\
\text { belum handal dan belum } \\
\text { dikelola secara terpusat; }\end{array}$ \\
\hline 2 & $\begin{array}{l}\text { Kebijakan/ aturan } \\
\text { belum } \\
\text { diterapkannya }\end{array}$ & $\begin{array}{l}\text { Kebijakan/ } \\
\text { dalam penggunan } \\
\text { perangkat dan layanan } \\
\text { belum ada dan belum } \\
\text { diterapkan. }\end{array}$ \\
\hline 3 & $\begin{array}{lr}\text { Kecepatan } & \text { transfer } \\
\text { kabel } & \text { masih } \\
\text { rendah } & \end{array}$ & $\begin{array}{l}\text { Kapasitas transfer data } \\
\text { pada kabel tidak } \\
\text { mendukung kebutuhan } \\
\text { masa kini; }\end{array}$ \\
\hline 4 & $\begin{array}{l}\text { Topologi jaringan } \\
\text { tidak sustainable. }\end{array}$ & $\begin{array}{lr}\text { Pembangunan } & \text { sistem } \\
\text { komputer dan keamanan } \\
\text { jaringan } & \text { tidak } \\
\text { memenuhi } & \text { kebutuhan }\end{array}$ \\
\hline
\end{tabular}




\section{No} Faktor

Keterangan

masa kini;

Berdasarkan uraian pada tabel 1 , dapat disimpulkan layanan internet dapat berjalan dengan maksimal, jika didukung oleh Optimalisasi desain LAN yang terintegrasi. Jaringan terintegrasi merupakan rangkaian yang menghubungkan beberapa perangkat, atau sistem kedalam satu jaringan, sehingga manfaat yang didapatkan dari solusi ini yaitu transparansi menyeluruh yang dapat mengelola jaringan dengan fleksilbilitas yang tinggi, manajemen Quality of Services dan memungkinkan untuk memprioritas trafik berdasarkan karakteristiknya $[4,5,6]$.

Desain jaringan komputer terintegrasi, harus dimulai dengan perencanaan. Tanpa perencanaan yang bagus, segala sesuatu yang melibatkan banyak perangkat menyebabkan dampak yang tidak terduga dan berakibat fatal $[7,8]$. Seperti pepatah yang sangat popular mengatakan "Mereka yang gagal dalam merencanakan, berarti merencanakan kegagalan" [7]. Perancangan ini menetapkan aturan standar jaringan yang harus diikuti oleh siapapun dalam pelaksanaan pembangunan infrastruktur jaringan (kabel, perangkat keras, dan perangkat lunak) dan memenuhi seluruh karakteristik arsitektur jaringan (fault tolerance, scalability, quality of service, dan security) $[3,4]$, serta dapat memberikan perlindungan terhadap investasi dan membuat layanan Internet berjalan dengan maksimal di Universitas XYZ.

Gagasan yang diambil dalam menyelesaikan isu utama ini adalah dengan melakukan Desain Jaringan Komputer Terintegrasi Menggunakan Arsitektur Campus LAN di Universitas XYZ. Hasil dari perancangan ini diharapkan menjadi panduan/pedoman untuk pelaksanaan dan pengadaan perangkat jaringan komputer yang terintegrasi, serta mendukung revitalisasi dan rencana strategis di Universitas XYZ.

\section{Gambaran Umum Kebutuhan}

Perkembangan Teknologi Informasi pada saat ini menjadi komoditas yang sangat penting. Kemampuan untuk mengakses informasi dan menyediakannya secara cepat dan akurat menjadi hal yang esensial bagi sebuah organisasi (komersial, perguruan tinggi, lembaga pemerintahan, maupun individu) [3]. Dengan perkembangan yang pesat dibidang teknologi informasi dan telekomunikasi, maka perlu dipertimbangkan bahaya dan kerugian atas penyalahgunaan dalam layanan jaringan lokal ataupun dalam aplikasi yang berbasis internet. Maka referensi menggunakan Arsitektur Campus LAN dipilih sebagai standar yang digunakan dalam rancangan desain jaringan komputer tersebut $[1,2,3]$.

Pendekatan arsitektur Teknologi Informasi Komunikasi dalam kajian ini adalah pendekatan arsitektur enterprise yang digunakan untuk logika pengaturan dan perencanaan seluruh organisasi, bertujuan menentukan bagaimana teknologi informasi akan mendukung proses bisnis. Cara ini diawali dengan mengidentifikasi kebutuhan infrastruktur dan keamanan jaringan, serta bagaimana kerja sama antar bagian atau unit kerja, bagaimana sistem teknologi informasi mendukung proses kegiatan, kemampuan teknis standar dan kegiatan untuk semua bagian dari layanan pendidikan, layanan administrasi dan sarana layanan lainnya [1,2]. Topologi Campus $L A N$ secara umum yang digunakan dapat dilihat pada Gambar 1. 


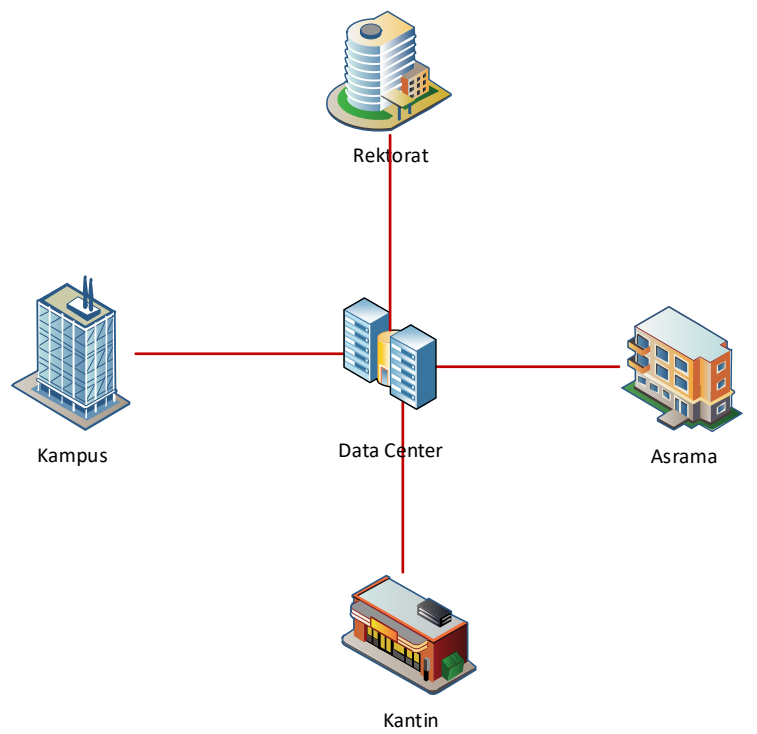

Gambar 1 Topologi Jaringan

Tujuan yang menjadi landasan arsitektur jaringan ini adalah Melakukan redesain terhadap sistem jaringan, seperti:

\section{a. Fault Tolerance (Toleransi Kesalahan)}

Sistem pengkabelan dibedakan menjadi 2 jalur ditribusi, yaitu: distribusi jalur kabel data dan distribusi jalur kabel listrik. Serta perapihan kabel pada wallmount/ rack dengan menggunakan patch panel untuk merapikan sistem port kabling.

Sehingga dengan rancangan seperti ini dapat menghilangkan berbagai resiko, seperti:

- Gangguan latency akibat interferensi elektromagnetik antar kabel;

- Sulitnya melakukan penelusuran gangguan kabel;

- Gangguan binatang terutama binatang pengerat dan lingkungan yang dapat mengakibatkan kerusakan sistem pengkabelan.

Distribusi kabel vertical tiap gedung/lantai menggunakan Fiber Optic (FO) $10 \mathrm{~Gb}$ dan distribusi kabel horizontal menggunakan kabel Ethernet Cat 7, hal ini dapat mendukung kecepatan akses data dikarenakan kebutuhan tiap perangkat sudah mendukung port gigabit ethertnet (GE).

\section{b. Scalability (Skalabilitas),}

Berdasarkan hasil survey dan wawancara yang telah dilakukan, perangkat yang ada saat ini sudah tidak mendukung kemampuan masa kini dan teknologi masa datang, hal ini dikarenakan perangkat dari tahun 2005 sudah lama tidak di upgrade atau diperbaharui dengan perangkat dengan teknologi yang mendukung teknologi terkini, maupun teknologi masa datang.

\section{c. Quality of Service (Kualitas Layanan)}

Berdasarkah hasil survey dan wawancara yang telah dilakukan terdapat beberapa masalah yang harus diperbaikin untuk perancangan selanjutnya, seperti:

1) Pengelolaan User dan Perangkat

Pengelolaan user dan perangkat masih dilakukan secara terdistribusi dan lokal, dimana pengelolaan user dan perangkat diakses didalam modul masing-masing aplikasi perangkat. Sementara akses ke dalam sistem komputer juga dikelola pada tiap unit yang ada di Universitas XYZ. Hal ini dikarenakan belum diterapkan sistem pengelolaan yang terintegrasi secara terpusat dan standar operasional pekerjaan (SOP) terhadap pengguna di lingkungan Universitas XYZ.

\section{2) Manajemen Bandwith Internet}

Pengelolaan layanan internet masih dilakukan secara bebas dan kecepatan akses internet untuk pengguna tidak dibatasi, menyebabkan layanan internet tidak maksimal.

\section{d. Security (Keamanan)}

Berdasarkan hasil survey dan wawancara yang telah dilakukan, beberapa hal yang harus diperhatikan, seperti:

1) Firewall

Perimeter keamanan logik yang utama yang diterapkan untuk melindungi jaringan dan sistem TIK Universitas XYZ adalah perimeter keamanan logik dalam bentuk firewall dan Demilitary Zone (DMZ). Perimeter ini memberi perlindungan dasar dari serangan hacker, sniffer atau pihak-pihak lain yang tidak 
memiliki kewenangan untuk masuk ke dalam sistem TIK Universitas XYZ terutama serangan yang datang jaringan publik (internet). Pada saat ini perangkat intrution prevention system/ intrution detection system (IPS/IDS) belum diterapkan sebagai perimeter keamanan logik.

2) Antivirus

Antivirus yang dipergunakan oleh Universitas XYZ pada umumnya ditujukan kepada perangkat komputer dan notebook yang digunakan pengguna. Jenis antivirus yang dipergunakan juga beraneka ragam, bergantung dari antivirus yang dipaketkan dari pembelian perangkat tersebut. Beberapa anti virus yang digunakan adalah Norton, Kasperky dan Mc Affee. Sementara pada lingkungan server, sebagian besar server tidak menggunakan antivirus mengingat sistem operasi yang digunakan adalah varian linux. Untuk serverserver berbasis Windows, diterapkan antivirus seperti yang telah disebutkan diatas. Pada saat ini belum dilakukan pengelolaan lisensi antivirus dan pengelolaan update terhadap antivirus. Update terhadap virus signature yang memungkinkan antivirus mendeteksi jenis virus terbaru dilakukan secara berkala dengan konfigurasi automaticaly update.

\section{3) VLAN dan VPN}

Pada saat ini seluruh jaringan LAN di gedung Universitas XYZ belum menerapkan virtual LAN. Sementara penerapan VPN telah diimplementasikan di dalam jaringan Universitas XYZ, salah satunya adalah penerapan VPN pada jaringan absensi, simpeg, efinance dan lain sebagainya.

\section{4) Patches dan Update}

Sebagian besar sistem operasi dan aplikasi serta antivirus secara umum dilakukan berkala dengan melakukan konfigurasi dalam sistem dengan modus automatically update. Disisi lain mekanisme update dan patches belum diatur secara terintegrasi sehingga sulit untuk mengetahui kondisi sistem apakah sudah menggunakan versi terbaru atau mengetahui apakah update/patches yang terbaru telah berjalan dengan baik dalam sistem yang ada.

\section{METODE PENELITIAN}

Penelitian ini dilakukan di Universitas $\mathrm{XYZ}$ dengan menggunakan metode eksperimen dan kajian pustaka. Pengujian dilakukan dengan melakukan survey lokasi dan wawancara terhadap pengguna layanan dan pengelola layanan.

\section{Desain Campus LAN (Local Area Network).}

Topologi Jaringan adalah susunan berbagai elemen seperti link, node, dan lain sebagainya dari sebuah jaringan computer [3]. Pada dasarnya struktur topologi jaringan dapat digambar secara fisik atau logis. Topologi fisik merupakan penempatan berbagai komponen jaringan termasuk lokasi perangkat dan instalasi kabel, sedangkan topologi logis mengilustrasikan bagaimana data mengalir dalam jaringan, terlepas dari rancangan fisiknya. Jarak antara node, interkoneksi fisik, tingkat transmisi atau jenis sinyal mungkin berbeda antara dua jaringan, namun topologi jaringan mungkin identik.

Sebagai ilustrasi adalah jaringan area lokal (LAN). Setiap node yang diberikan dalam LAN memiliki satu atau lebih link fisik ke perangkat lain dalam jaringan, grafis pemetaan ini hasil link dalam bentuk geometris yang dapat digunakan untuk menggambarkan topologi fisik jaringan. Sebaliknya, pemetaaan aliran data antara komponen menentukan topologi logis dari jaringan.

Local Area Network (LAN) merupakan infrastruktur jaringan yang mempersiapkan akses ke layanan dan sumber daya komunikasi jaringan untuk pengguna akhir dan perangkat yang tersebar di satu lantai atau gedung [3]. Anda membuat jaringan kampus dengan menghubungkan kelompok LAN yang tersebar di wilayah geografis kecil. Konsep desain jaringan kampus adalah jaringan kecil inklusif yang menggunakan switch LAN tunggal, hingga jaringan yang sangat besar dengan ribuan koneksi $[1,3]$.

Campus LAN memungkinkan komunikasi antara perangkat di gedung atau kelompok bangunan, serta interkoneksi ke 
WAN dan ujung Internet di inti jaringan. Campus LAN menggunakan model desain hierarkis untuk memecah desain menjadi kelompok atau lapisan modular [3]. Memecah desain menjadi beberapa lapisan dan memungkinkan setiap lapisan untuk mengimplementasikan fungsi-fungsi tertentu, serta menyederhanakan desain jaringan, penyebaran dan pengelolaan jaringan [3,4].

Perubahan arsitektur jaringan yang menyatu dan terpusat, cenderung dapat mempengaruhi sejumlah besar sistem. Desain hierarkis membantu membatasi perubahan operasional ke subset dari jaringan, yang membuatnya mudah untuk dikelola serta meningkatkan ketahanan. Penataan modular jaringan menjadi elemen kecil dan mudah dipahami serta memfasilitasi ketahanan melalui perbaikan kesalahan isolasi [3,4].

Hirarki Desain Campus LAN mencakup tiga lapisan, seperti pada Gambar 2.

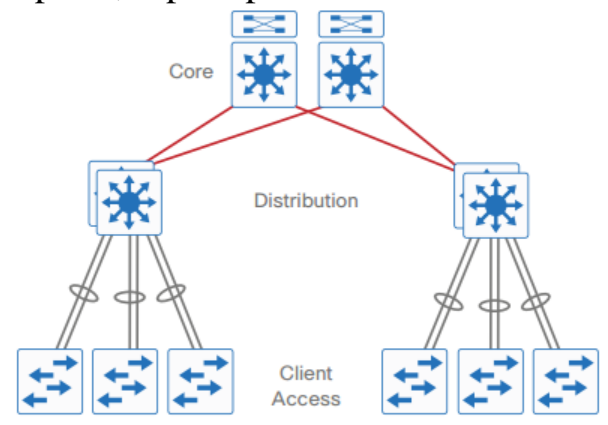

Gambar 2 Hirarki Desain Campus LAN

\section{Core Layer (Lapisan Inti):}

Menyediakan konektivitas antar Distribution Layer untuk lingkungan area yang besar [3]. Dalam lingkungan LAN besar, sering muncul kebutuhan untuk memiliki beberapa lapisan switch distribusi. Salah satu alasannya adalah ketika lapisan switch akses terletak di beberapa bangunan yang tersebar secara geografis, Anda dapat menghemat pemasangan fiber-optic di antara gedung dengan menempatkan lapisan switch distribusi di setiap bangunan tersebut $[1,3]$.

Dalam lingkungan yang banyak lapisan switch distribusi berada dalam jarak dekat dan dimana fiber-optic menyediakan kemampuan untuk interkoneksi high-bandwidth, lapisan core dapat mengurangi kompleksitas jaringan, dari $\mathrm{N} *(\mathrm{~N}-1)$ ke $\mathrm{N}$ links untuk $\mathrm{N}$ distribusi, seperti yang ditunjukkan pada Gambar 3 dan Gambar 4.

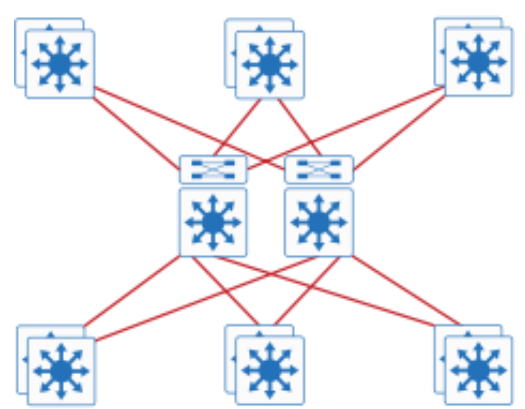

Gambar 3 Topologi LAN dengan Lapisan Core

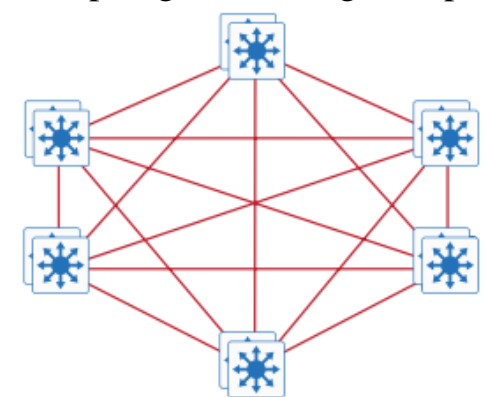

Gambar 4 Topologi LAN Tanpa Lapisan Core

Lapisan Core merupakan bagian terpenting LAN untuk skalabiltas jaringan dan salah satu desain yang paling sederhana. Lapisan distribusi menyediakan kontrol kesalahan dan domain, dan core merepresentasikan $24 \times 7 \times 365$ konektivitas tanpa henti, organisasi harus memiliki lingkungan bisnis modern di mana konektivitas ke sumber daya dalam bisnis sangat penting. Konektivitas pada Core mendukung sampai ke Layer 3, yang mendorong peningkatan ketahanan dan stabilitas.

\section{Distribution Layer (Lapisan Distribusi):}

Menggabungkan Lapisan Core dengan Lapisan Access untuk menyediakan konektivitas ke layanan. Lapisan distribusi memisahkan lapisan akses dari lapisan layanan. Lapisan ini menyediakan metode distribusi layanan yang secara terpisah memisahkan trafik berbasis bisnis ke dalam aliran, dan memungkinkan skala ketika pegawai dipindahkan, ditambahkan, atau diubah. Lapisan distribusi juga berfungsi sebagai titik 
agregasi untuk beberapa lapisan switch akses [3].

Lapisan distribusi dapat menurunkan biaya operasional dengan membuat jaringan lebih efisien, sehingga kebutuhan memori sedikit, membuat kesalahan domain berdasarkan pengelompokkan kegagalan atau perubahan jaringan, dan memproses sumber daya untuk perangkat di tempat lain dalam jaringan. Lapisan distribusi juga meningkatkan ketersediaan jaringan dan kualitas layanan (QoS) dalam aliran aplikasi untuk menjamin aplikasi penting dan aplikasi multimedia berfungsi sebagaimana dirancang [3]. Topologi LAN menggunakan lapisan distribusi seperti pada Gambar 5.

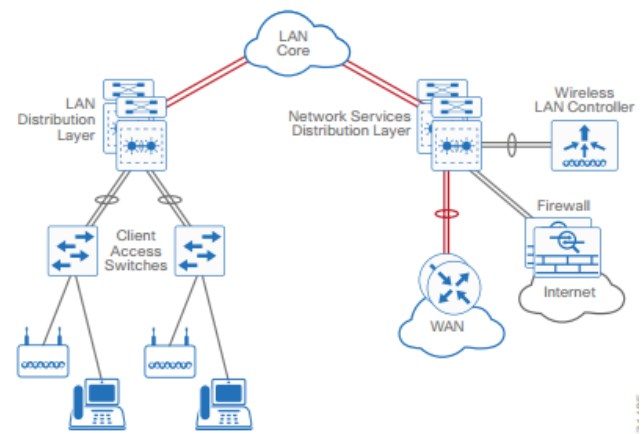

Gambar 5 Topologi LAN dengan Lapisan Distribusi

\section{Access Layer (Lapisan Akses):}

Memberikan titik akhir dan pengguna akses langsung ke jaringan. Lapisan akses merupakan tempat perangkat user-controlled, perangkat user-accessible, dan perangkat endpoint lainnya yang terhubung ke jaringan. Lapisan akses menyediakan konektivitas kabel dan nirkabel dan berisi fitur dan layanan yang menjamin keamanan dan ketahanan untuk seluruh jaringan [3]. Topologi LAN menggunakan lapisan akses seperti pada Gambar 6.

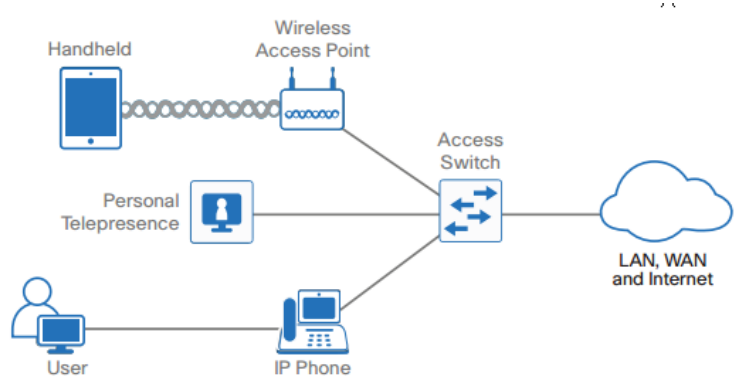

Gambar 6 Topologi LAN dengan Lapisan

Akses

Lapisan Akses terhubung langsung dengan jenis perangkat akhir (end-devices) seperti: Komputer Pribadi, IP Phone, AP Nirkabel, CCTV dan lain sebagainya. Lapisan akses dapat mendukung banyak jaringan logis, memberikan manfaat untuk kinerja, manajemen, dan keamanan $[1,4]$.

\section{HASIL DAN PEMBAHASAN}

Hasil dari penelitian ini adalah menyusun rancangan sistem monitor dan pengaturan perangkat aktif dan jaringan secara terpusat berdasarkan skalabilitas untuk kebutuhan di masa yang akan datang sehingga dapat memberikan perlindungan terhadap investasi.

Arsitektur Campus LAN memiliki karakteristik sebagai berikut:

- Lokasi terdiri dari beberapa bangunan/lantai yang memiliki banyak aliran layanan;

- Banyak perangkat yang membutuhkan konektivitas jaringan;

- Perangkat (sensor, cctv, ip phone, printer, dll);

- Peralatan terpisah untuk layanan, redundansi dan uptime maksimum;

- Konektivitas nirkabel;

- Layanan aplikasi lokal (pusat data atau cloud).

Arsitektur Campus LAN dibuat kedalam desain yang logis, seperti pada Gambar 7. 


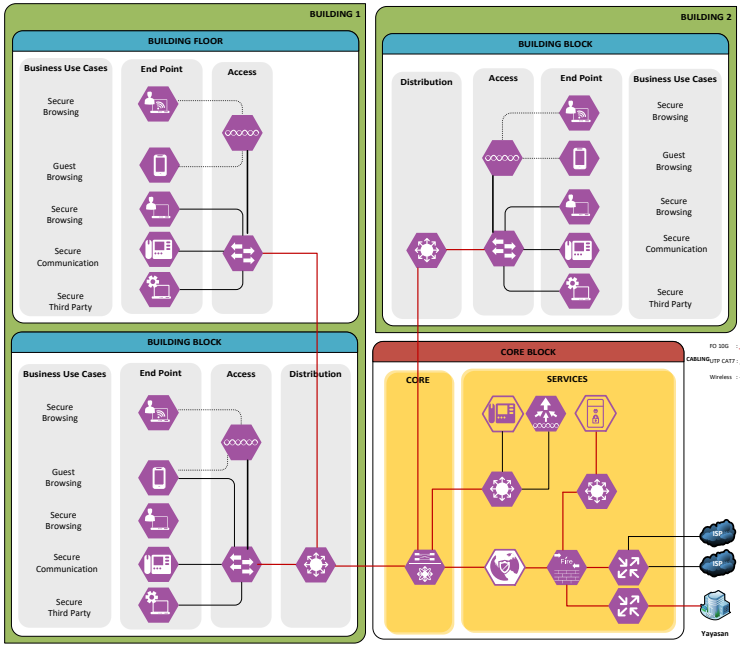

Gambar 7 Desain Arsitektur Campus LAN

Berdasarkan Gambar 7 Arsitektur Campus LAN di Universitas XYZ menganut hirarki sebagai berikut:

a. Lapisan Inti (Core Layer)

Lapisan Inti adalah jaringan inti berkecepatan tinggi, layanan forwarding dengan performance yang tinggi dalam memindahkan paket data antara lapisan distribusi dalam jaringan.

b. Lapisan Distribusi (Distribution Layer)

Lapisan Distribusi atau workgroup layer yang menerapkan titik komunikasi antara access layer dan core layer. Fungsi utama lapisan distribusi adalah mempersiapkan routing, filtering dan menentukan cara terbaik untuk menangani permintaan layanan dalam jaringan. Setelah lapisan distibusi menentukan lintasan terbaik maka kemudian permintaan diteruskan ke core layer. Core layer dengan cepat meneruskan permintaan itu ke layanan.

c. Lapisan Akses (Access Layer)

Lapisan Akses disebut juga sebagai lapisan desktop dan mengendalikan akses pengguna dengan workgroup ke sumber daya internetwork. Desain lapisan layer diperlukan untuk menyediakan fasilitas akses ke jaringan. Fungsi utamanya adalah menjadi sarana bagi suatu titik yang ingin berhubungan dengan jaringan luar.

\section{KESIMPULAN}

Berdasarkan hasil penelitian yang telah dilakukan maka dapat disimpulkan bahwa Isu kontemporer tentang lambatnya layanan internet di Universitas XYZ bukan hanya disebabkan oleh kecilnya bandwith yang tersedia saat ini, tetapi ada beberapa faktor jaringan area lokal (LAN) yang belum optimal dan menyebabkan layanan internet tersebut lambat, seperti: topologi jaringan yang tidak sustainable, manajemen layanan dan perangkat, dan kapasitas perangkat yang sudah tidak mendukung kebutuhan. Oleh karena itu, perlu dibangun Desain Jaringan Komputer Terintegrasi menggunakan Arsitektur Campus $L A N$ yang sudah mendukung aspek arsitektur jaringan (fault tolerance, scalability, quality of service, dan security).

\section{REFERENSI}

[1]. Mulyawan, Bagus., Campus Network Design And Implementation Using Top Down Approach: A Case Study Tarumanagara University. Preoceedings of The $1^{\text {st }}$ International Conference on Information Systems For Business Competetiveness, 2011.

[2]. Ali, Muhammed., et al., Design and Implementation of a Secure Campus Network, International Journal of Emerging Technology and Advanced Engineering, Volume 5, Issue 7, 2015.

[3]. Team, Cisco., Validated Design Cisco: Campus LAN and Wirelles LAN Design Guide, USA: Cisco Validated Design, 2018.

[4]. Team, Cisco., SAFE Architecture Guide Place in The Network: Secure Campus, USA: Cisco SAFE Simplifies Secure, 2018.

[5]. Alam, Syahirun., et al., Sistem Evaluasi Kinerja Campus Area Network. Teknik Elektro Fakultas Elktro Fakultas Teknik Universitas Muhammadiyah Parepare, 2011.

[6]. Wahid, Aceng Abdul., et al., Perancangan 
Jeckson Sidabutar

Submitted, 3 Februari 2020, Revised: 25 Maret 2020, Accepted: 15 April 2020; Published: 27 April 2020

Konsep Smart Campus Menggunakan Jaringan Internet of Things (IOT). Jurnal Ilmu Informatika dan Manajemen STMIK, 2019.

[7]. Sofana, Iwan., Membangun Jaringan Komputer: Mudah Membuat Jaringan Komputer (Wire \& Wireless) untuk Pengguna Windows dan Linux, Bandung:
Informatika, 2015.

[8]. Pratama, I Putu A.E., Handbook Jaringan Komputer: Teori dan Praktik Berbasiskan Open Source, Bandung: Informatika, 2015. 